\title{
Restructuring as a Clue to Unleashing Nigeria's Potentials and Prosperity
}

\author{
Aaron Onyemaechi Nwokolo \\ http://dx.doi./org/10.4314/ujah.v21i3.10
}

\begin{abstract}
The continuous misgivings about Nigeria's developmental trajectory predate Nigeria's independence. The clues that can unravel and demystify the mystery surrounding the continuous retardation of socio-political and economic well-being of Nigeria have over the years become a tall order. Using the qualitative method, this paper succulently highlighted restructuring as a veritable panacea for promoting peaceful co-existence amongst ethnic nationalities, and also encourages healthy competition among federating units or states. This paper further discussed restructuring as it relates to resource control by sub-national government. It recommended power devolution and deloading of the exclusive list of 1999 constitution as amended and galvanizing the states and local government towards assuming more governmental responsibilities.
\end{abstract}

Keywords: Federalism, Political Restructuring, Clue, Devolution, Autonomy.

\section{Introduction}

The current debate on re-structuring has thrown up various view points and further enrich the subject matter. At various fora stakeholders, opinion moulders, political elites and academics have various shades of opinion and perspectives as regards restructuring. These various perspectives are anchored majorly on political, ethnic, religion and economic linings. Some schools of thought are canvassing physical federalism or restructuring, others are pushing for 
resource control and power devolution and the amendment of the constitution to enable the federating units (states and local Governments) leverage on devolution of power to harness local mineral resources and developed according to their pace. The current structure of governance clearly negates the principle, spirit, and the practice of federalism. The current order is at best clueless and cannot engender development and prosperity for Nigerian citizens.

While researcher and academics do not all agree on a single definition for federation, it has been described as a governmental structure consisting of at least two constituent parts that are not wholly independent but together form the system as a whole. Wheare opined that federalism is "the method of diving powers so that the general and subsidiaries governments are each, within a sphere, coordinates and independent". This characterization was criticized for failing to take into account the similarities and interrelationship that characterized twentieth century federal systems. Others have taken a much broader view of federalism viewing it as a process instead of a design or focusing on institutional issues.

Later approaches have instead focused not on precise definitions but on specific elements that characterize and differentiate federal systems. Riker approach considers federalism as a concept of "political organization in which the activities of government are divided between regional governments and a central government in such a way that each kind of government has some activities on which it makes final decision". Watts classified federalism as "the advocacy of multi-tiered government combining elements of shared-rule and regional self-rule. Also, recent literature has tended to acknowledge the heterogeneous nature of federal systems depending on specific traits. Hence, some federal systems have been described as either quasi, weak, loose or partial.

Beyond the attempts at conceptualization, scholars have also focused on determining why nations adopt federalism or the federal 
political system. Dicey identified two predisposing elements- the connection of the federating units and the existence of a sentimental desire of the federating units to form a union despite their individual identity. Essential features of federalism across several jurisdictions include: a supreme constitution; constitutional distribution of powers between the national government and the sub-national government; Supreme Court (or other dispute resolution mechanism) to resolve dispute over distribution of power; adequate number of sub-national governments and equality of states.

Lyttleton constitution of 1954 introduced federalism in Nigeria. The system was retained at independence in 1960, 1963, 1979 and 1999. Since then, Nigeria has had to contend with several challenges in applying the federal model to achieve national integration. These relate to designing acceptable institutions and structures as well political processes.

The perceived imbalance in the federal structure and the concentration of power in the centre has led to continuous agitations for political restructuring of Nigeria. These agitations have a long history, beginning with the creation of the modern Nigerian state by British colonialists. It started with the dilemma of the British on how to effectively govern the colony and effectively manage the 'natives' to guarantee the maximum exploitation of their resources. The act of amalgamation of the colony of Lagos and the protectorates of southern and northern Nigeria in 1914 was an apt solution to the dilemma at the time. However, in the course of colonial rule and the emergence of nationalist agitation for self-government and independence, the colonial authorities had to confront the emergent political realities as underscored by the politicization of ethnic and regional identities, which the colonial state actively encouraged through its divide and rule strategies.

The creation of three regions in the aftermath of increased demand for political participation by the emergent nationalists and the 
re-organization of provinces within the regions in the 1950s was equally a part of the political restructuring aimed at creating more or less stable administrative units that can promote effective governance. Not surprisingly, Nigeria's independence was the outcome of a series of negotiation between different regional elites mediated by British colonial administrators at conferences in Lagos and London in the late 1950s.

Since attainment of independence, the structure of the Nigerian Federation or the perceived imbalance in the structure of Nigeria as a federation and the fiscal arrangements underlying the federal system have remained problematic and contentious in spite of efforts such as the creation of additional region and subsequently states and power has very much remained centralized.

It is against this background that this study examines the reasons behind the activism for political restructuring of Nigeria. Specifically, it assesses the reports of various national conferences and constitutional review exercises relevant to the topic and analyzes the various shades of opinions of Nigerians presented by the six geopolitical zones in Nigeria (North-West, North-Central, North-East, South-West, South-South and South-East). Although it is difficult to establish a coherent understanding of restructuring as put forward by the different groups and individuals making the agitations, this study captures the nuances surrounding their demands.

\section{Phases of Agitation for Political Restructuring in Nigeria}

Five phases of Nigeria's political history can be clearly defined for the purpose of identifying the waves of agitations for political reforms or restructuring. The first phase is the period from 1914-1947. In the aftermath of amalgamation of Northern and Southern protectorates to form what became known as Nigeria, there was no avenue for national interaction. Western, Eastern and Northern regions were governed separately by the British colonialist. Most agitations were 
limited to the Lagos area with some crop of Nigerian elites emerging to challenge discrimination against Nigerians in the public service and demanding for opening up of the political space for competitive politics and especially participations in the colonial legislative organs.

The phase two is the period from 1947 to 1966 . By 1947, under the Richards constitution, the British brought the three regions of the country together in a legislative council. Shortly before this, a number of indigenous political leaders had begun to agitate for greater opportunity for Nigerians to govern their affairs, and not just to be accorded due place in the public service. The agitations later focused on gaining independence. This was followed by negotiations on when the country should become independent of British colonial rule and the shape an independent Nigeria should take. The political leadership and the British eventually settled for the federal system, parliamentary government and inclusion of fundamental human rights provisions in the constitution, among others. These arrangements were sustained into independence until the military take -over of power in January 1966.

The phase three is the period from 1966 to 1983 which introduced military rule to Nigeria and signals the beginning of the abolition of the constitution and gradual erosion to the federal system. This sparked of political agitations, which combined with the serious conflicts that resulted from the first and second military coups (January and July 1966), pushed the country into a civil war from 1967 to 1970 . Consequently, there was a general tendency on the part of the military and civil political leadership to prefer a centralized federal system and a chance of the fiscal arrangement from the pre1966 fiscal remained in place with near unanimous agreement of the political leadership until the military takeover of December 1983. There were little or no significant agitations on the structure of the federal system between 1979 and 1983. Most agitation focused on restoration of democratic rule and ensuring political inclusion. The 
brief period of democratic rule from 1979 to 1983 was marked rather by agitation over governance, including questions of public accountability. Structural issues did not dominate political agitations except that the removal of derivation principle had begun to generate some discontent in the oil-producing section of the country now regarded as the south-south geo-political zone.

The phase four is the period from 1983 to 1999 which saw several waves of agitations including for restoration of democratic rule, reform of Nigeria's federal system to devolve more powers to the states and issues of creation of more states. The annulment of the June 12, 1993 presidential election sparked intense agitations for the military government to return power to civilians. This particular agitation rallied pro-democracy agitators to insist on a sovereign national conference to resolve issues of Nigerian's political future including issues of whether Nigeria should remain a single sovereign country, or the acceptable federal system to be adopted, among other issues. It was during this period that the idea of re-structuring the country into six zones. It was also during this period that vociferous agitations commenced in the south-south geo-political zone on environmental degradation resulting from an oil exploitation and a future distribution of proceeds of oil resources.

The phase five is the period from 1999 to date which has also seen intense agitations over a number of issues on federal structure such as devolution of powers, fiscal federal arrangement; and other specific issues of governance such as public accountability, electoral reform, strengthening of political institutions, federal character and state creation. Political dynamics, such as those associated with power sharing at the federal level, politics of succession since the death of president Umaru Yar'adua, politics of re-election/second term under President Jonathan and President Buhari's coming to power, combined to fuel the agitations. Key resolutions of the conference deal directly with the several contentious issues in Nigeria's federal 
system and the quest for restructuring including revenue allocation, structure of government, power sharing/rotation and states creation.

In 2014, President Goodluck Jonathan set up a presidential committee under Justice Belgore to review outstanding issues in constitutional amendment, covering the period between 2001 and 2014. This became necessary following continued agitation for the amendment of the 1999 Constitution by different sections of the country and civil society organizations. Some of the thematic issues that relate to the quest for restructuring covered by the recommendations of the presidential committee include the following: states creation, constitutional recognition of geo-political zones, revenue allocation, derivation and resource control, devolution of powers, local government autonomy and local government autonomy.

President Goodluck Jonathan's national conference of 2014 discusses contentious issues that threatened national unity and make recommendations for addressing them through constitutional and policy reforms measures. The clear fault lines among Nigerians were reflected in the course of deliberations at the conference. Whereas the South-west and South- east groups pushed for devolution of powers, and advocated that the existing six zones should replace the 36 states as federating units in the federal system, the North-central (Middle Belt) group, comprising largely minority ethnic groups, was mostly concerned about marginalization and stoutly defended creation of more states in order to cater for the smaller minority groups within their multi-minority states.

The South-south group, sharing the same fears of minority domination, preoccupied itself with the right of resource control under the states and not zones or regions. Finally, the 'core Northern' (North- west and North-east) groups were prepared to allow only minor amendments to the 1999 Constitution while they sought to retain most of the provisions relating to power and revenue sharing in the current federal arrangement. The period that followed the 2015 
general elections in Nigeria has been marked by the resurgence of identity politics accompanied by demands for restructuring the Nigerian federal system. Several interest groups are making determined calls for restructuring.

These range from what can be referred to as moderate calls to tinker with the federal structure of the country (i.e. devolution of power from the federal to the state governments), to rigid demands for reverting to the old regional structure, which obtained in the First Republic, or a slight variation of it, dubbed as "true-federalism", to the more extremist demands for secession, and for the creation of an independent state of Biafra, by a group calling itself the Indigenous People of Biafra (IPOB).

In addition, many prominent Nigerians who influence public opinion have contributed to the to the debate and numerous interest groups across the federation have either held, or are currently in the process of holding, conferences, stakeholder consultations, and other forms of engagements, to aggregate their respective views and positions on restructuring, with a view to coming up with their stand on the issue of restructuring. In addition, the All Progressives Congress (APC) government of President Muhammadu Buhari has also created the Committee on True Federation to engage with members of the public on the following issues: creation/merger of states, derivation principle, devolution of powers, federating units, fiscal federalism \& revenue allocation, form of government, independent candidacy, land tenure system, local government autonomy, power sharing \& rotation, resource control, type of legislature and any other matters.

\section{Research Methodology}

The research is largely qualitative geared at exploring the underlying reasons for recent surge in the calls for political restructuring of Nigeria's federal system. Both primary and secondary data were 
utilized in the course of the study. Secondary data consisted mainly of a desk review of existing research studies in this area.

The primary research which was undertaken over a period of four (4) months (August to November 2019) was carried out using a structured/semi-structured interview schedule and guide to interview respondents across the states in all the six geopolitical zones. A total number of 167 (South West: 19; North East: 13; South East: 15; South-South: 62 North-Central: 32; North-West: 26) were interviewed from the six geopolitical zones. An open-ended questionnaire was used to elicit a wide range of responses on key thematic issues pertaining to restructuring, namely: the question of unity of Nigeria, creation of states, creation of local governments, distribution of power and resources among federating units, revenue generation and sharing, etc.

The use of open-ended questionnaire was prompted by the depth of the information required including the historical and political context as well as the need to capture the nuances involved. The approach provides for flexibility that enables probing into relevant issues that could be raised by respondents even when such issues were not anticipated in the design of the instrument. A purposive sampling technique was adopted based on the knowledge of the lead researchers of individuals with the requisite knowledge and understanding of all the issues provoking the agitation for restructuring.

The choice of this approach necessarily involved some form of sampling considering the vastness of the country, the time and resources available allocated to the task of the study. The selection of the individual respondents was based on an informed assessment of their respective standing nationally and in their communities/states as technocrats, academics, diplomats, elder statesmen, retired public office holders, respected community leaders, distinguished business personalities, retired high level public and civil servants, politicians 
and technocrats that have participated in national conferences and other dialogue platforms over the years and critical stakeholders, both men and women, and based on their previous wealth of experiences in the service of the nation in various capacities.

Furthermore, consideration was given to gender representation in drawing the sample of respondents to the questionnaire. Sampling of respondents was purposive and limited to opinion moulders and shapers in communities whose views and interests appear to drive the demand and agitation for restructuring and who are also knowledgeable about the issues. The respondents in the study were therefore drawn from a wide spectrum of the society including the academia, technocrats, politicians, traditional rulers, retired military and police officers and the different professionals such as lawyers and journalists as well as civil society activists.

\section{Outcomes, Findings and Discussions}

This study has made a number of useful findings regarding the concerns of Nigerians about restructuring the Nigerian federation both in terms of distribution of power and resources among the different tiers of government and issues that relate to the continued existence of Nigeria as a corporate entity. The key findings of the study are reported under the thematic issues below.

\section{Nigeria's Integration/Unity}

The unity and continued existence of Nigeria as an indivisible unit is one of the key issues on which this research seeks to establish the view of respondents across the six geo-political zones. Despite variation in sentiments expressed by Nigerians regarding the level of unity and the extent to which sentiments about national cohesion differ, there is widespread acceptance that Nigeria should remain a united country. There is a strong feeling that national unity and peaceful co-existence should be reinforced. 
Across the geo-political zones, respondents identified historical and contemporary factors that have inhibited Nigeria's unity. These include the arbitrary amalgamation of 1914 by Britain without any proper negotiation and integration of the various ethnic nationalities; attachments of Nigerians to primordial sentiments over and above that of Nigeria as a political community; lack of justice, fairness and equity in the distribution of resources and opportunities among the different entities that make up Nigeria; rising culture of impunity and the inability or perceived refusal of government to protect lives and property; and increasing poverty and unemployment in the country/ failure of governance to address issues of livelihood and social provisioning.

Other issues raised by respondents include mass disenchantment with the political elite and national leadership; a feeling or sense of alienation or of being oppressed harboured by minority groups; the infamous distinction between indigenes and settlers; and the various insurrections and insurgencies in the country particularly in the South-South, South-East and the North-East. Some of the respondents emphasized deliberate politicization of ethnic and religious diversity by the political elites and persons described as 'conflict merchants' as a key obstacle to national unity and integration. Respondents explained this in terms of the activities of a 'divisive' rather than a 'divided' economic, power and political elite who present their interests as those of their ethnic or religious communities particularly when they fail to achieve personal ambitions.

\section{The Nigerian Structure}

The study establishes a general discontent with the structure of the Nigerian federation as presently constituted. The preponderant opinion is that powers and responsibilities are over concentrated at the centre (federal) at the expense of the states. Many of the respondents 
therefore, strongly suggest that the powers and resources of the federal government should be reasonably reduced. Thus, restructuring seems to be perceived more in terms of reduction of the powers of the federal government and transferring some of these powers to the states, accompanied by the additional resources to the states to enable them carry out additional responsibilities.

The general view is that the strident calls for resources control and the resurgence of regionalist and secessionist tendencies point to the flaws that exist in Nigeria's federal system. Nevertheless, opinions vary in terms of the approach to restructuring. For instance, majority of the respondents in the states in the South-East zone favour a restructuring of Nigeria along regional lines with the geo-political zones 1 as the federating units. A similar view was shared by majority of respondents in the south-west who state that a return to regionalism similar to the federal arrangement in Nigeria's First Republic is the best approximation of the restructuring that Nigeria needs. By extension, the view of these zones is that regions, rather than states, should be the federating units.

\section{Revenue Allocation}

There are commonalities and differences among the six geo-political zones on what the structure revenue allocation should be. In all the zones of the country, there is consensus that the present system of vertical revenue, which assigns more revenues to the federal government, should be reviewed in favour of states. The present formula gives the Federal Government 52.6\%; State Governments $26.72 \%$; and Local Governments $20.60 \%$. The overwhelming view of the respondents is that in an 'ideal' federal system, the federating units have more development functions and thus deserve higher share of revenue allocation. This view is held by respondents in all the zones regardless of whether they agreed that states and local government should be federating units or that only states should be 
federating units. Furthermore, it is argued that ceding more powers to states will compel them to improve on their internal revenue generation capacity by focusing on the development of their natural endowments in agriculture, solid minerals, etc. This in turn, it is contested by some respondents, will bring to an end has been characterized as Nigeria's feeding bottle federalism' whereby states and local governments are fiscal appendages of the centre (federal).

On the principles for horizontal allocation of revenues, there are minor disagreements but they do not necessarily amount to major divisions. For example, a clear majority of the respondents in the south-east, south-south, south-west and to a significant extent, northcentral, agree that population, rather than land mass should be assigned the greatest weight in revenue allocation. However, a significant number of respondents (particularly from Niger and Kogi States) insist that more emphasis should be given to land mass. This line of argument is also supported by states in the North-East and North-West geo-political zones.

The argument put forward, for example, by states that relatively have vast geography is that this has direct consequence for physical distance of populations to health and education facilities. Primary school enrolment, minimum responsibility of government and equality of states received varying levels of support in revenue allocation among the states.

However, some respondents in the North-West and the NorthEast zones of the country stated that other criteria such as poverty index, level of educational development indicated by primary school enrolment, infrastructural deficit and number of children out school hitherto not entrenched into horizontal revenue sharing should be considered. On the whole, a sizeable number of respondents express the view that dialogue and negotiations are viable options for building consensus on these contentious issues. They further observed that the current formula for vertical revenue sharing is not arbitrary but based 
on specific agreed upon criteria including the powers and responsibilities assigned to each tier of government in the Nigerian Constitution. In the event of devolution of powers, any resulting review of these powers and responsibilities should be accompanied by a corresponding review of the percentage of revenue accruable to each tier. This is to enable each tier fund the set of responsibilities assigned to it.

Furthermore, a significant number of respondents maintain that any reform of revenue sharing system among the three tiers of government should be accompanied by a review of existing tax assignments, which, in the current structure, appear to put the states and local governments at a disadvantage. It is suggested that the principle of subsidiarity should determine which level of government carries out which responsibility. Taxing powers of governments should also factor in efficiency and capacity of the various levels of government.

On the principle of derivation spelt out in Section 162(2) of Nigeria's 1999 constitution which presently assigns 13\% derivation to the producing states, there is consensus among respondents in most of the zones that the percentage share accruable to states should be increased and indeed that states should be being allowed to keep substantial parts of their resources. Furthermore, many of the respondents state that doing such would reduce dependence on oil resources and push states to explore and develop their natural endowments and resource and further reduce dependence on federation allocations. Some of the respondents argue that emphasis should shift from revenue sharing to revenue mobilization and creation of wealth in every state.

It was further argued that since every state in the federation is endowed in natural resources of one kind or another, with the initial investment and good governance, each state can become self-reliant and pursue meaningful development. This appears as the dominant 
view in the South-East, the South-South, South-West and NorthCentral zones of the country. Some of the respondents observe that historically, when Nigeria was divided into autonomous regions with substantial financial autonomy drawn from derivation, they recorded significant achievements and competed among each other resulting in more development in the regions.

Additionally, some of the respondents simply adopt the position of ethno-regional organisations like Ohaneze N'digbo and Afenifere supporting an increase in the share of allocation. The argument is that given the potential of all states in the country to be self-reliant, a reworked derivation principle in favour of states will, in the final analysis, be beneficial to all. The overwhelming view is that derivation be assigned a weight of not less than $50 \%$.

\section{The State of Local Government in Nigeria}

Despite variations in opinion across the country on the status of local governments, there is substantial support for local government autonomy in most of the zones. This receives overwhelming support in South-South, North-Central, North-West and North-East where it is argued that local governments should be given considerable autonomy to perform development functions envisaged in the wave of post- independence reforms targeted at strengthening local governments that 1976. Most Respondents are in support of granting local government autonomy and advance various reasons for their views.

To some, it will bring government closer to the people by giving them opportunity to have access to those who are in government and share their developmental aspirations. To others it will bring about rapid development encourage the development of leadership at the local level by building a pool of leaders for the higher levels of government. Many respondents express concerns about the systematic stifling of governance at the local level owing to 
flawed elections conducted by the state independent electoral commissions which are beholden to state governors. Indeed, state governors seem to prefer appointing Sole Administrators and constituting Caretaker Committees for the councils, which are often populated by cronies, rather than holding democratic elections, which are constitutionally required.

\section{Powers Devolution and Resources}

There is general support across the six geo-political zones that devolution of power is imperative to re-federalize Nigeria by reviewing the long Exclusive Legislative List in the 1999 Constitution and transferring those issues best tackled by states and local governments to them alongside a review of revenue allocation in favour of states and local governments. Although there is a lack of clarity on the specific nature of power to be devolved, a significant percentage of respondents note that issues that most directly impact on citizens such as primary health care, education, and agriculture are purely state responsibilities even if federal government has a role in setting national minimum standards, regulation, and funding research. There was also significant support for giving states control of solid minerals, which are widely distributed in states of the federation.

On the issue of state police or what many of the respondents recognized as multi-level policing, most of the respondents from the South-South and the North-Central zones approve of state police to address and effectively tackle the multifarious security challenges besetting the country including kidnapping, herder/farmer conflict and other forms of banditry. The views among respondents from the North-West zone are not unanimous.

\section{Role of the National Assembly in the Restructuring Agenda.}

The dominant view among respondents across the country is that the National Assembly should consider the recommendations on 
restructuring from Nigerians and the various national conferences with a view to making appropriate constitutional amendments. Most respondents argue that the legislators are the elected representatives of the people and are constitutionally empowered to amend the constitution. In addition, they maintain that it will be cost-effective and expeditious for the National Assembly to handle the issues on agitation for restructuring based on the popular opinion of the citizens. A reasonable number of respondents show preference for a National Conference apprehensive that if left in the hands of politicians, they are likely to advance positions favorable to their collective interest rather the national interest and wishes of Nigerian citizens.

\section{Rotation of Power among Geopolitical Zones/Senatorial Districts}

On the question of rotation of power, there is near consensus by almost all respondents from the North West. It is widely held that power rotation constitutes one of the most important components of the agitation for restructuring and an acceptable way of promoting national unity and a sense of belonging in the federal arrangement. It is argued by proponents that the current system and structure manifestly marginalizes some sections of the country, particularly minority ethnic groups. The respondents who object to the idea of power rotation contend that it is antithetical to democratic principles.

\section{States Creation}

There is clearly a lack of unanimity on the issue of creation of new states with many of the respondents suggesting that creation of additional states could lead to the proliferation of weaker states in relation to the federal government and thus compound an already problematic situation. Many point to the overbearing power of the federal government fuels demands for additional states. However, those who oppose state creation argue that it will inflate the cost of 
governance which is already particularly high in Nigeria. They thus advocate for constitutional clauses that prohibit the creation of additional states in Nigeria. However, a significant number of respondents express support for the creation of additional states as a means to addressing the marginalization of some minority groups. Respondents from the South-East Zone strongly feel that an additional state should be created in the zone to ensure parity in the number of states in the old three regions of the First Republic.

\section{Conclusion and Policy Recommendations}

The study has demonstrated that the current agitations to restructure the country predominantly centre on issues of the political structure of Nigeria such as the powers distributed to the federal government and the states (or devolution/decentralization of powers); the fiscal federal arrangements; the appropriate number of federating units; state creation; the status of local government councils; the appropriate platform or mechanism to effect restructuring (whether through a national conference or referendum or the National Assembly) and rotation of power. Nonetheless, the study also shows that in addition to the foregoing structural issues, there are several issues of governance which have direct link to persistent agitations among Nigerians.

The study also reveals certain general areas of convergences, for instance the widely held agitations for political restructuring in Nigeria are heightened by factors that include: high levels of corruption (and the retention of immunity clause for elected presidential and gubernatorial office holders thereby shielding them from criminal prosecution, despite alarming allegations of corruption and abuse of power); ever widening inequality gaps, prevalent poverty and very low living standard among a vast majority of the people; high unemployment and under-employment rates especially among the youth population; prohibitive cost of governance 
underscored by higher budgetary allocation to recurrent expenditure at the expense of capital expenditure; weak state capacity and government institutions, self-serving rather than developmental elite, failure to manage pluralism (religious and ethnic), outdated and bloated bureaucracy, bad governance and ineffective leadership marked by lavish life-style, and poor management and implementation of public policy.

Despite unanimity on the above, there are also areas of noticeable divergences. For instance, in the South-South, South-West, North-East and the South East, there are agitations against violation of or non-compliance with the federal character provisions of the constitution in the appointment of public officers. These issues do not feature in the other zones. Secondly, in the North Central and SouthSouth zones, there are agitations against marginalization of minorities by the major ethnic groups.

Many respondents from those zones are of the view that minorities do not feel properly integrated in the federal structure, especially at the national level. Furthermore, in the North Central there is a widespread view that persistent struggle for political power leads to a negative and often time destructive competition for power which once attained is used for the benefit of the group in power rather than national interest. Also, in the North Central, South-South, South West and the South East, there is a strong feeling of insecurity as a result of inter-ethnic and inter-religious suspicions and violent clashes; and the increasing phenomenon of herders/farmers violent clashes. In the South-South part of the country serious concerns are raised on the growing phenomenon of 'conflict merchandizing' underscored by deliberate sponsorship of conflicts by some leaders for political purposes and to gain access to state resources. Similar views are expressed in the North Central where it is said that sometimes politicians who lose out in political contests are unwilling 
to accept such outcomes fate and instead resort to violence or generate conflict in order to regain lost political power.

Finally, in the North West, the leading cause for tension and rising agitations for restructuring is the denial of opportunity for political participation and governance suffered especially by the youths, women and the less privileged in society. The following recommendations are drawn from the study. The first relates to deepening Nigeria's federalism by promoting greater autonomy for states and local governments in the forms of devolution/ decentralization of power and resources. Also, essential is a review of the existing revenue allocation/sharing formula, both vertical and horizontal and strengthening institutions and mechanisms for periodic review of the formula.

Similarly, devolution of powers should be pursued through Constitutional amendment. In this regard, the National Assembly may have to reconsider the rejected Devolution of Powers Bill, 2017, as a means of ensuring effective transfer of certain powers currently exercised by the Federal government to the States. In distributing powers and resources amongst the tiers of government, Nigeria can draw important lessons from other federal countries (USA, Canada, Australia, Germany, Switzerland, India, Ethiopia and South Africa), particularly on how to effectively organize the federation based on recognized principles of subsidiarity, proportionality and solidarity.

The subsidiarity principles help to determine the often challenging question of which tier should exercise what powers for the purpose of ensuring effective and efficient delivery of public goods and services. The principle of proportionality is useful in factoring in all contending interests in the process of distribution of powers. The solidarity principle, on its part, is an indispensable mechanism for accommodating the generality of the populace in whatever fiscal federal arrangement instituted in the country. In designing the Exclusive and Concurrent Lists, the principles of 
subsidiarity and proportionality should be adopted. For example, in keeping with the principle of subsidiarity, matters such as basic education, primary health care and intra-city roads which can be better handled by states and local governments rather than the federal government. Also, consistent with the proportionality principle, interstate commerce issues such as high way policing, inter-state crime, collection of taxes across states, construction of highways and environmental spill-overs (pollution) should be handled through cooperative federalism with leadership by the federal government. These principles should also be used to determine which matters should be consigned to the Residual Legislative List. Finally, in keeping with the principle of solidarity, the federal government has a responsibility to guarantee a minimum level of living standards to all Nigerians irrespective of their state of origin or residence. This implies that the federal government can allocate resources for equalization, bridging gaps and addressing fiscal imbalance in the allocation of resources.

Specifically, it is recommended as follows: The Exclusive Legislative List which outlines powers of the centre should consist of the following: (i) Ports and Central Banking (Items 6, 36); (ii) Issue of currency (Item 15); (iii) Customs \& Excise duties (Item 16); (iv) Defence (Item 17); (v) Foreign affairs (Item 20); (vi) Immigration and emigration (Item 30); and (vii) Aviation (Item 3). Secondly, the Concurrent Legislative List, which spells out powers shared by the federal and state governments, should consist of the following: (i) Tertiary Health; (ii) Tertiary Education; (iii) Power (Items 13 and 14); (iv) Custom and excise (Item 16); (v) Evidence (Item 23); (vi) Police (Item 45) and (vii) Railways (Item 55). Finally, the Residual Legislative List (which come under the jurisdiction of the states) should consist of the following: (i) Primary Health; (ii) Basic Education (Items 27, 28,29, 30) (iii) Agriculture (Items 17, 18, 19, 20); and (iv) Road construction (Item 11). 
Other specific recommendations include granting financial autonomy to states, who are to contribute an agreed proportion to the central government for its effectiveness; the creation of one more state in the South-East Zone to ensure parity; power rotation between the geo-political zones engender political inclusion; lessening the appeal of power at the national level by pursuing power devolution and other measures; and promoting inclusive framework for ethnic, religious and regional accommodation. Furthermore, it is important to engender good governance and ensure that governments resources are effectively utilized to promote common and collective good of the citizens.
Aaron Onyemaechi Nwokolo
Department of Political Science
College of education, Agbor
onyeaaronqgmail.com

\section{References}

Ayoade J (1998) The Federal Character Principle and the Search for National Integration. In Amuwo K, Agbaje A, Suberu R \& Herault G (Eds.), Federalism and Political Restructuring in Nigeria, Ibadan: Spectrum Books.

Dicey AV (1885) Introduction to the Study of the Law of the Constitution (1st edn.): Macmillan.

Duchacek ID (1970) The Territorial Dimension of Politics. New York: Holt, Rinehart and Winston.

Friedrich C (1968) Trends of Federalism in Theory and Practice. London: Pall Mall.

Herault (Eds.), Federalism and Political Restructuring in Nigeria, Ibadan: Spectrum Books.

Hueglin T, Fenna A (2006) Comparative Federalism: A Systematic Inquiry. Peterborough: Broadview Press. 
McCormick J (2011) European Union Politics. Basingstoke: Palgrave.

Moravcsik A (2001) European Federalism: Rhetoric and Reality. In $\mathrm{K}$ Nicolaidis \& $\mathrm{R}$ Howse (Eds.), The Federal Vision: Legitimacy and Levels of Governance in the United States and the European Union Oxford: Oxford University Press, pp: 161-187.

Osadolor OB (1998) The Development of the Federal Idea and the Federal Framework, 1914-1960. In K Amuwo, R Suberu, A Agbaje \& G

Peil M (1976) Nigerian politics: The Peoples View. London: Cassell. Citation: Dan-Azumi J, Jega A, Egwu S (2019) The Challenge of Re-Federalizing Nigeria: Revisiting Recent Debates on Political Re-Structuring . J Pol Sci Pub Aff 7: 353. doi:10.4172/2332-0761.1000353 Page 8 of 8 J Pol Sci Pub Aff, an open access journal ISSN: 2332-0761 Volume 7 • Issue $1 \cdot 1000353$

Piris JC (2006) The European Union: Towards a New Form of Federalism? In J Fedtke \& B Markesinis (Eds.), Patterns of Regionalism and Federalism: Lessons for the UK, Oxford: Hart, pp: 69-87.

Pollack M (2010) Theorizing EU Policy-making. In H Wallace, M Pollack \& A Young (Eds.), Policy-making in the European Union, Oxford: Oxford University Press, pp: 15-44.

Riker W (1975) Federalism. In F Greenstein \& N Polsby (Eds.), Handbook of Political Science, Reading: Addison-Wesley 5: 93-172.

Sbragia A (1992) Thinking About the European Future: The Uses of Comparison. In A Sbragia (Eds.), Euro-politics: Institutions and Policymaking in the 'New' European Community, Washington: Brookings Institution, pp: 257-291. Wheare KC 
(1964) Federal government. London: Oxford University Press.

Tamuno, T.N. (1989) Nigeria: Its people and its problems. Nigeria federalism in crisis: Critical perspectives and political options, Ibadan: John Archer Publishers.

Vile MJC (1961) The Structure of American Federalism. Oxford: Oxford University Press.

Wallace W (1996) Government Without Statehood: The Unstable Equilibrium. In $\mathrm{H}$ Wallace \& W Wallace (Eds.), Policymaking in the European Union, Oxford: Oxford University Press, pp: 439-460.

Watts RL (1996) Comparing Federal Systems in the 1990s. Montreal: McGill-Queen's University Press. 